Jurnal Ilmu Komunikasi

Vol. 12, No. 2

ISSN: 2085 - 4609 (Print), e- ISSN 2656-0208

Journal homepage: bit.ly/UltimaComm

\title{
\#BodyProudMums: Promoting Body Positivity through Brand Storytelling on Social Media
}

\section{Ruvira Arindita}

To cite this article:

Arindita, R. (2020). \#BodyProudMums: Promoting Body Positivity through brand Storytelling on Social Media, UltimaComm: Jurnal Ilmu Komunikasi, 12(2), 319-341. DOI 10.31937/ultimacomm.v12i2.1321.

Ultimacomm publishes research articles and conceptual paper in the field of communication, mainly digital journalism and strategic communication. It is published twice a year by the Faculty of Communication of Universitas Multimedia Nusantara

Submit your article to this journal $₫$ 


\title{
\#BodyProudMums : Promoting Body Positivity through Brand Storytelling on Social Media
}

\author{
Ruvira Arindita \\ Universitas Al Azhar Indonesia \\ Email: ruvira.arindita@gmail.com
}

Received Dec.10, 2019; First Revision on Sept. 28, 2020; Second Revision on Nov. 20, 2020; Accepted Dec. 22, 2020

\begin{abstract}
Previous researches showed that there is relation between body image satisfaction and depression in perinatal period. Given this fact, it is important to educate and find ways to enhance mothers' postpartum self-esteem and body satisfaction. For the last decade body image literature has risen and brought to new discussion about body positivity. This research focuses on women's body positivity campaign presented by Mothercare called \#BodyProudMums. The objective of this research is to identify the storytelling elements used to promote women's body positivity campaign and whether the issue creates good brand story for Mothercare. The concepts used are body positivity, postpartum, brand storytelling, and social media with qualitative content analysis as research method. The unit of analysis are ten posts of \#BodyProudMums campaign on @mothercareuk,while the samples are three randomly chosen posts. This research notes that the body positivity messages of body appreciation, body acceptance, and love, as well as broad conceptualization of beauty are carried out by the elements of storytelling namely: basic plots (the quest), archetype (the change master) with the following story objectives: communicating who they are, fostering collaboration, transmitting values and sparking action. There are only three out of four elements of good brand story present on the campaign. However, the absence of humor element is justified because of the nature of the postpartum story in which it shares mothers' hardship and how they finally cope with it. Therefore, it can be said that the issue of mothers' body positivity creates good brand story for Mothercare.
\end{abstract}

Key words: positive body image, postpartum, brand storytelling, social media

\section{INTRODUCTION}

Women have always been encouraged to change their shape and to conform to current trends (Grogan, 2017). Macquarie, a researcher from the University of Sidney, found that women are more likely to compare themselves with others (Martanatasha \& Primadini 
2019). The reason is that because women commonly value their body based on the value given by society and culture (Murwani, 2010).

Motherhood, as beautiful as it seems, has brought new challenges for women. There are numerous changes happen once women become a mother. Sleep deprivation, rising and falling hormone levels, stress over breastfeeding or guilt over bottle feeding, the juggle of going back to work and caring for children at home are just a few of the stressors take place particularly in the first few months postpartum. A study shows that the postpartum period places the mother and infant at risk of a number of negative health outcomes. Mental health conditions, such as depression and anxiety, are common in the postpartum, as is poor body image. (Kellie, 2017)

Woman's body image can be significantly affected by the rapid and extensive physical changes during pregnancy and postpartum. Pregnancy is a complicated period for women in that it is often the first-time weight gain is expected and accepted (Hodgkinson, Smith, \& Wittkowski, 2014). However, it does not apply the same to postpartum. A study in the journal Body Image reveals that postpartum women have high levels of body image dissatisfaction since there was pressure to lose weight and "snap back". It also has been a source of sadness, and even depression. A negative body perception in postpartum period increases the likelihood that those new moms will encounter other psychological distress (Meireles et al., 2015).

A study conducted in 2009 highlighted that mothers' body satisfaction worsened from one to nine months postpartum (Gjerdingen et al., 2009). A similar research in 2015 concludes that there is theoretical and epidemiological evidence supporting an association between body image satisfaction and depression in the perinatal period (Silveira et al., 2015). Given these relationships, it is important to educate women about expected postpartum weight and body changes, and to find ways to enhancing mothers' postpartum self-esteem and body satisfaction.

In the last decade, the body image literature has begun to extend beyond focus on body image disturbances, and examine the construct of positive body image. Similarly, Body positivity is a growing social media trend that seeks to challenge dominant societal appearance ideals and promote acceptance and appreciation of all bodies and appearances (Cohen et al., 2019). The earlier research showed that a brief exposure to body positive posts was associated with improvements in young women's positive mood, body satisfaction, and body appreciation. It was concluded that body-positive content may offer a fruitful avenue for improving young women's body image (Cohen et al., 2019). 
Body Positivity is a common cause used for emotional branding which is described as a way to engage with customers, appealing to their needs, aspirations, dreams, and ego. This branding strategy addresses the growing trend of consumers' seeking emotional relationships with a brand (Acharya, 2018).

Dove Campaign Real Women Real Beauty was a one of the pioneers in emotional branding strategy, which tried to promote body positivity among women. The campaign started in 2004 and is still going on today. Previously there were several researches conducted on women's body image campaign by Dove. One experiment resulted that while exposure to the Dove model versus an ultra-thin model was not related to decreased levels of self-discrepancy across experimental groups, numerous other statistically significant relationships emerged based on exposure to the Dove or plus-size model (Bissel \& Rask, 2010).

Other research analyzed Dove Campaign in connection with the concept of femvertising. The research shows that those Dove's series of advertisement are indicating the similar issue, that is dictating body standard, style, and women beauty, that occur for a long time, had increasing women's anxiety on their body. Their anxiety of body image is removed at the end of advertisement with comfortable feelings and confidence. (Kumalaningtyas \& Sadasri, 2018).

Dove is not the only brand that promotes women body positivity issue. Women's postbirth body image has been rarely talked about publicly until Mothercare launched a campaign called \#BodyProudMums in December 2018. This campaign boldly seeks to normalize mother's experience, spark a positive conversation, and help mothers to feel confident and proud of their bodies. On the shots, mothers are shown holding their babies close, and are smiling as the kids laugh, gawp at the camera in bemusement, or, in some cases, scream their heads off. The inspiration behind this project was to show real women, all different shapes and sizes actually not caring about their 'big' thighs or 'big' bellies - and just trying to be comfortable in their own skin. The ads appear in more than 30 Tube stations across London, on LCD screens and escalator panels (Seymour, 2019). 
Picture 1. Photos of \#BodyProudMums Campaign
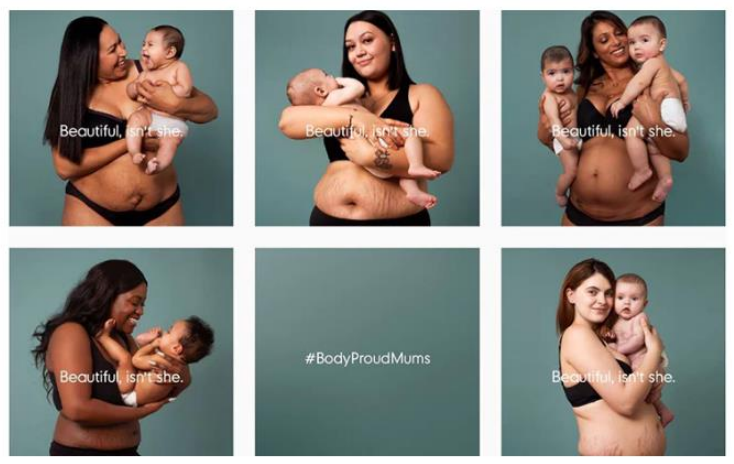

(Source: https://www.instagram.com/mothercareuk/)

The campaign itself is the product of brand storytelling in which a story or narrative is conveyed through the brands communication medium. Storytelling is used to connect the identity or philosophy of company in creating a product or describing the production activity (Salzermorling \& Strannegard, 2004). Storytelling is a fundamental human activity because through it people are able to better understand their world and organize their experiences to communicate them to others. It also plays a role in persuasion, because the best way to persuade someone is by telling a compelling story (Delgado-Ballester \& Fernández-Sabiote, 2016).

Initially The Body Proud Mums campaign was created for London's "The Women We See" competition. The campaign was also published on Mothercare official Instagram. Later, it has gone viral. Mothers from all around the world started to post their own postpartum photo and stories on their Instagram account. As of now, the hashtag \#BodyProudMums on Instagram hits about 2,379 posts, with mostly show the honest photos of how their body appearance after giving birth.

The swift spread of the campaign is the outcome of the use of social media. Social media, as the result of development of science and technology, has provided a space to communicate, socialize, and express ourselves (Dewi \& Winduwati, 2019). The rapid usage of the Internet as a tool or medium of communication and information, including media campaign to society, is popular to spread idea(s), thought, even ideology. (Nasucha \& Kertanegara, 2020). McQuail (2011) noted several qualities of social media, namely providing social presence, creating a feeling of being connected with others, giving the autonomy (feelings in control), allowing interactivity, and bringing joy and playfulness. Schiffman and Kanuk (2010) added that social media is addressable, in which the message can be conveyed both to public and private, interactive and easily distributed. 
As mentioned above, women postpartum negative body image is a real thing that poses threat to both mothers and their child. Mothercare, as mother and baby product brand, took the chance to educate women about the expected postpartum body changes through the campaign. The campaign itself uses storytelling method in which real mothers from various ethnicities tell story about how they cope with their postpartum body image. Their photos and stories are displayed on Mothercare's UK Instagram account and have sparked positive conversation among mothers. Based on the reason of how important women's body image issue and how powerful brand storytelling on social media, the objective of this research is to identify the storytelling elements used to promote women's body positivity campaign \#BodyProudMums and to identify whether the issue creates good brand story for Mothercare.

\section{LITERATURE REVIEW}

\section{Positive Body Image (Body Positivity)}

Previous research on body image and body positivity has seen this topic through the lens of social media exposure. The one conducted by Martanatasha and Primadini (2019) tried to find out the relation of self-esteem and body image within the exposure of social media Instagram. Through the surveys among college students, the study showed an indirect effect between those three variables. In other words, it can be said that social media Instagram can affect the body image and in turn can also affect self-esteem (Martanatasha \& Primadini, 2019).

Another research on positive body image was carried out in relation with femvertising (Kumalaningtyas \& Sadasri, 2018). This research elaborated how body positivity was being described through the concept of femvertising. Through the content analysis of Dove's Real Beauty video, this research resulted that the series of Dove advertisement has shown similar issues about body standard, looks, and women beauty, as well as the rise of women's anxiousness about their body. Their restlessness about their body finally vanished in the end of advertisement and changed by the confidence. All of that scenes showed the representation of femvertising concept (Kumalaningtyas \& Sadasri, 2018).

While the previous two researches above discussed body image and body positivity from communication science, these following other researches have looked from another discipline's view: psychology. The first one, carried out by Frisén and Holmqvist in 2010, aimed to investigate positive body image during adolescence. Semi-structured interviews, centering on three body image domains (satisfaction with own appearance, views on exercise, and influence from family and friends) were conducted with 30 early adolescent Swedish girls and boys aged between 10 and 13. Results revealed that the adolescents' 
satisfaction with their own appearance was characterized by a functional view of the body and an acceptance of the bodily imperfections that they perceived that they had. The vast majority of the adolescents were physically active and found exercise joyful and health-promoting (Frisén \& Holmqvist, 2010).

Secondly, a research conducted by Barcalow, Tylka and Horvarth in 2010 has tried to find out about positive body image characteristics for young-adult women. This study used Grounded Theory to analyze interviews from 15 college women classified as having positive body image and five body image experts. Many characteristics of positive body image emerged, including appreciating the unique beauty and functionality of their body, filtering information in a body-protective manner, defining beauty broadly, and highlighting their body's assets while minimizing perceived imperfections (WoodBarcalow et al., 2010).

From the previous research, it was noted that body image is about how we feel towards our body. Body image is not only about how we look physically but it is about our feelings about our appearance (Taylor, 2014). The concept body image on this research refers to the definition of positive body image according to Wood-Barcalow et al. (2010). In a multi-dimensional concept, positive body image has to represent body appreciation, body acceptance and love, broad conceptualization of beauty, adaptive appearance investment and filtering information in a body-protective manner (Kumalaningtyas \& Sadasri, 2018).

The first one, body appreciation, is about feature, functionality and body health, specifically being thankful of what the body can do (Avalos et al., 2005). Second, body acceptance and love, is about the expression of love and comfort towards one's body, even if not fully satisfy with all aspect in our body (Frisén \& Holmqvist, 2010). Third, broad conceptualization of beauty, refers to the perception that the definition of beauty could be obtained from various looks (Wood-Barcalow et al., 2010). The fourth aspect, adaptive appearance investment, notes that individual with positive body image has the tendency to do self-care which projects their personal style and personality (Wood-Barcalow, 2010). Fifth, filtering information in a body positive manner, is an aspect that describes how individual manage the exposure of information "unrealistic and fabricated nature of media images". Individual with positive body image will be better in managing critics related to their looks (Wood-Barcalow et al., 2010).

\section{Brand Storytelling}

The brand storytelling research conducted by Delgado-Ballester \& Fernández-Sabiote in 2016 shows that nowadays, companies are making efforts to build their brands through 
storytelling. The aim of this exploratory research was to analyze the use of storytelling practice by Spanish companies. Content analysis was applied to identify differences among companies that use or do not use storytelling, and the characteristics and elements used were analyzed. The results showed the main objectives of the stories, the plots and the archetypes used, among other aspects. Nevertheless, storytelling was underused by most Spanish companies and there was room to increase the quality of stories (Delgado-Ballester \& Fernández-Sabiote, 2016).

Secondly, the research by Kaufman in 2003 investigated the place that storytelling has in company's communications, and stated that storytelling has a wide and varied range of applications. This research revealed various organizations' views on where storytelling adds value and how leaders can use this better to develop their organizations in the global context. It concluded that those bonds thus provided better returns on both personal and organizational levels (Kaufman, 2003).

Thirdly, the research by Denning in 2006 aimed to answer about how a CEO make effective use of storytelling. The finding of this research highlighted that even executives, who are naturally talented at narrative, also need to learn to targeting their approach in particular issue faced by the company. Leading companies increasingly recognize the need to train leaders in using artful narrative, in an attempt to inspire and guide their organization so it can respond effectively to strategic challenges. But the reality shows that most organizations need help to get the full benefits of using storytelling (Denning, 2006)

A brand story comprises a realistic or fictional framework in which brand can be embedded to convey something about the brand's heritage, founder, highlights and crises, mission and values, functional, and emotional benefits. The literature has highlighted four elements that contribute to a good brand story: authenticity, conciseness, reversal and humor (Delgado-Ballester \& Fernández-Sabiote, 2016).

As another element of a brand story, plots play a central role because they are an essential attribute that organize events into a beginning, a middle, and an end. They help to order experiences and make them meaningful via a logical sequence (Delgado-Ballester \& Fernández-Sabiote, 2016).

Finally, the use of archetypes in the brand story helps to connect with consumers, and also to present products and brands in a meaningful way. Archetypes are forms or images of a collective nature that represent a typical human experience and define the personality of a brand, and give it a voice to express its story to the consumer (DelgadoBallester \& Fernández-Sabiote, 2016). 
Table 1. Elements of Brand Storytelling

\begin{tabular}{|l|l|}
\hline Good Brand Story & Authenticity, Conciseness, Reversal, Humor \\
\hline Story Objectives & $\begin{array}{l}\text { Sparking action, Communicating who you are, Sharing } \\
\text { knowledge, Transmitting value, Taming the grapevine, Leading } \\
\text { people to the future, Communicating who the brand is, Fostering } \\
\text { collaboration }\end{array}$ \\
\hline Basic Plots & $\begin{array}{l}\text { Rags to Riches, Rebirth, The quest, Overcoming the monster, } \\
\text { Tragedy, Comedy, Voyage and return }\end{array}$ \\
\hline $\begin{array}{l}\text { Archetypes (universally } \\
\text { familiar character) }\end{array}$ & $\begin{array}{l}\text { Ultimate strength, The siren, The hero, The antihero, The } \\
\text { creator, The change master, The powerbroker, The wise old } \\
\text { man, The loyalist, The mother of goodness, The little trickster, } \\
\text { The enigma }\end{array}$ \\
\hline
\end{tabular}

(Source: Delgado-Ballester \& Fernández-Sabiote, 2016)

Storytelling is one of the oldest and most powerful modes of communication (Kaufman, 2003; Worth, 2008), not only because from childhood we are used to reading, listening and telling stories, but also because stories are easier to remember (Lundqvist et al., 2013). In a branding context, storytelling is also reaching a significant status in companies' brand-building efforts and brand strategy communications in terms of persuading consumers and strengthening the brand externally (Delgado-Ballester \& FernándezSabiote, 2016).

Following the abovementioned previous researches on body image, body positivity, and brand storytelling, the researcher concluded that there was no research conducted about body positivity campaign for mothers (postpartum women) in relation with the elements of brand storytelling. Thus, this brings the researcher to raise these following research questions:

RQ1 : How is the issue of mothers' body positivity being promoted by storytelling elements?

RQ 2 : How does mothers' body positivity issue create good brand story for Mothercare?

\section{METHODS}

This research uses qualitative content analysis (QCA). QCA is a method for systematically describing the meaning of qualitative material. This is done by classifying parts of research's material as instances of the categories of a coding frame. The method is suitable for all material that requires some degree of interpretation. This can be verbal or visual, and it can be material that is being generated for the research, or material that is sampled from other sources. The material of this research are the posts under \#BodyProudMums campaign on the official Instagram account @mothercareuk. QCA 
requires the researcher to focus the analysis on selected aspects of material, as indicated by research question. On this research, the selected aspects of materials include the texts that contain main concepts, namely body positivity and brand storytelling (Schreier, 2012).

With the aim to discover how women body positivity issue being promoted by storytelling elements and how the issue creates good brand story for Mothercare, this research takes narrative analysis approach. The central idea of narrative analysis is that stories and narratives offer especially translucent windows into cultural and social meanings. Stories are at the center of narrative analysis. How to interpret the text that tell the stories is at the heart of narrative the analysis. The analysis also reveals about the person and the world from which it came (Patton, 2002).

On this research, the stories of postpartum women are the center of the analysis. The elements of brand storytelling concept are used to interpret the text of \#BodyProudMums on Instagram. The narrative would like to reveal the value that the brand brings in the campaign.

According to Mayring (2014), the research process of qualitative content analysis requires research instrument to categorize the data. The categorization is created by the formulation of the research question followed by the theoretical and conceptual frame. After the categorization process is done, the researcher is doing the coding by analyzing the research material using the categorization unit. The interpretation of research material can be presented only if the previous step is in accordance with the research question. 
Table 2. Unit of Analysis

\begin{tabular}{|c|c|c|}
\hline Unit of Analysis & Category & Sub Category \\
\hline \multirow{2}{*}{$\begin{array}{l}\text { Instagram Post of } \\
\text { Mothercare's } \\
\text { \#Bodyproudmum } \\
\text { Campaign }\end{array}$} & Photo & Photo of pospartum women and their babies \\
\hline & Caption & $\begin{array}{l}\text { Tells stories about the women's perception on their pospartum } \\
\text { body image }\end{array}$ \\
\hline \multirow[t]{5}{*}{ Positive Body Image } & Body appreciation & Awareness of body's uniqueness feature \\
\hline & $\begin{array}{l}\text { Body acceptance and } \\
\text { love }\end{array}$ & Confidence and affection towards one's body \\
\hline & $\begin{array}{l}\text { Broad conceptualization } \\
\text { of beauty }\end{array}$ & $\begin{array}{l}\text { The understanding that beauty concept is beyond the physical } \\
\text { appearance }\end{array}$ \\
\hline & $\begin{array}{l}\text { Adaptive appearance } \\
\text { investment }\end{array}$ & $\begin{array}{l}\text { Tendency and willingness to do self-care to project individual's } \\
\text { personality and personal style }\end{array}$ \\
\hline & $\begin{array}{l}\text { Filtering information in a } \\
\text { body positive manner }\end{array}$ & $\begin{array}{l}\text { The way individual manage the exposure of information related } \\
\text { to body image }\end{array}$ \\
\hline \multirow{31}{*}{$\begin{array}{l}\text { Brand Storytelling } \\
\text { Elements }\end{array}$} & \multirow[t]{4}{*}{ Good story elements } & Authenticity \\
\hline & & Conciseness \\
\hline & & Reversal \\
\hline & & Humour \\
\hline & \multirow[t]{8}{*}{ Story objectives } & Sparking action \\
\hline & & Communicationg who you are \\
\hline & & Sharing knowledge \\
\hline & & Transmitting values \\
\hline & & Taming the grapevine \\
\hline & & Leading people into the future \\
\hline & & Communicating who the brand is \\
\hline & & Fostering collaboration \\
\hline & \multirow[t]{7}{*}{ Basic Plot } & Rags to riches \\
\hline & & Rebirth \\
\hline & & The quest \\
\hline & & Overcoming the monster \\
\hline & & Tragedy \\
\hline & & Comedy \\
\hline & & Voyage and Return \\
\hline & \multirow[t]{12}{*}{ The Archetypes } & Ultimate strength \\
\hline & & The siren \\
\hline & & The hero \\
\hline & & The Antihero \\
\hline & & The Creator \\
\hline & & The Change master \\
\hline & & The Power broker \\
\hline & & The Wise old man \\
\hline & & The Loyalist \\
\hline & & The Mother of goodness \\
\hline & & The Little trickster \\
\hline & & The Enigma \\
\hline
\end{tabular}




\section{RESULTS}

Below are the three randomly chosen \#BodyProudMums posts taken from Mothercare's official instagram account @mothercareuk with the photo and stories told on the caption. Each posts will be analysed by using the elements of positive body image and brand storyteling.

Table 3. \#BodyProudMums Post

\begin{tabular}{|c|c|}
\hline Photo 1 & Caption \\
\hline & $\begin{array}{l}\text { Eleanor, } 14 \text { weeks after giving birth: } \\
\text { The inspiration behind being part of this project is to show } \\
\text { those around me that stretch marks and weight gain don't } \\
\text { define us, that we should embrace our strength and beauty. } \\
\text { I am a young mother with many influential people around } \\
\text { me, and together we can see the beauty of motherhood.I } \\
\text { have always loved my body no matter what, and my friends } \\
\text { would look up to me for that. Pre-pregnancy, I had nice } \\
\text { curves and my skin was smooth. During pregnancy my body } \\
\text { changed dramatically, not just in weight - but also my } \\
\text { breasts and skin, in the ways that aren't considered to be } \\
\text { beautiful. I've seen people on social media bounce back } \\
\text { significantly and speedily to their pre-pregnancy weight, so } \\
\text { of course I feel the pressure to do so too. I have found it } \\
\text { difficult to see my body in the same way, but as the days go } \\
\text { by, I am a few steps closer. I didn't expect my body to } \\
\text { change as much as it did, but I would most definitely do it } \\
\text { all over again." }\end{array}$ \\
\hline
\end{tabular}

(Source: https://www.instagram.com/p/BuTWXLUlufl/)

The good brand story elements shown on Eleanor's story are authenticity and conciseness. The stretchmarks and weight-gain are common condition happened to postpartum women. Eleanour sends a strong message that she refused to be defined by those changes happened in her body. Instead, she chooses to see the beauty of motherhood. By saying these things, Eleanor shows the elements of positive body image, namely body appreciation, acceptance, and love. The way she delivers her story also shows conciseness. In a relatively short description, we can get what she means and we are brought to her stituation.

The objectives of this story are to spark action, transmitting values and fostering collaboration. The action that Eleanor suggests the pospartum women is for them to embrace the new body they have and to not define themselves merely by the strecth mark or weight gain. The values being transmitted here are body appreciation, body 
acceptance and body love. It was shown by her statement "I have always loved my body no matter what, and my friends would look up to me for that". The way Eleanor shares her postpartum experience could prompt the other mothers to share their own stories about the same topic. The basic plots on Eleanor's story is about the quest. She admitted that she did feel the pressure to bounce back and speedily get to her pre-pregnancy weight. She also said that she found difficulty to see her body the same way. However, she mentioned that as the the days go by "I am a few steps closer". Thus, her statements are in accordance to the definition of "The Quest", that is about the progression Eleanor would like to have from the state of feeling negative about her appearance towards a better self-acceptance.

The brand archetype shown on Eleanor's post is "The Change Master". It is about representation of transformation, self-improvement, and the desire to be the master of our own destiny. It was clearly stated by Eleanor that she wanted to get closer to accepting the new body she has. She might feel negative towards her new body and feel pressure to get back to her pre-pregnancy body from her surroundings (media and society), but then she refused to be solely defined by her weight. Even she mentioned that she would love "to do it all over again".

Table 4. \#BodyProudMums Post

\begin{tabular}{|l|l|}
\hline Photo 2 & Caption \\
\hline Tina, 27 weeks after \\
"I am not a fan of my new body. Before birth I was muscular and \\
worked out a lot. Now I don't have time to work out and everything \\
feels saggier! I didn't expect to feel suddenly so old and droopy! I \\
know it will come back with time and dedication to exercise again, \\
but right now all I want to do is cover up with baggy clothes. \\
Every day I feel pressure to bounce back. Society, social media, \\
people's comments all make you feel that way. All over social media \\
it shows these perfect bodies saying they've had children and now \\
bounced back so quickly. I, myself remember being really surprised \\
when Kate Middleton came out of the hospital holding Prince George. \\
She had the baby bump, and I remember being surprised that your \\
belly doesn't just go down after giving birth. I also thought how \\
stupid I was to have ever thought it would. I guess pre children you \\
just have unrealistic expectations. I also put pressure on myself to try \\
and get my body back, but as I slowly transition into motherhood I \\
am realising that it's actually not that important, and I just need to be \\
OK in my own skin rather than worrying about what everyone else \\
thinks."
\end{tabular}

(Source: https://www.instagram.com/p/BuTImwOFSYk/) 
Tina's story has the elements of authenticity, conciseness, and reversal. The authenticity is shown by the complaints she has about her own body. The complaints she has are similar with what other mothers experienced. Mostly are about the change of the body, and the facts that mothers' body are saggy and droopy. The feelings toward their new body is negative. She also feel pressure to bounce back quickly from social media and society around her. The reversal moment came when she watched the news about Kate Middleton, The Duchess of Cambridge, who came out of the hospital holding Prince George and still had the baby bump. That moment really hit her. She realised that mothers' belly does not just go down after giving birth.

The objective of the story is to communicating who she is as Tina reveals some vulnerability from her past experience to inspire and engage others. She described how she only wanted to cover her body with baggy clothes to hide the new body she feels dissatisfied about. She also said how much she feels pressure from society and media to bounce back to her pre-pregnancy shape. But in the end, she realized that she is in a transition into motherhood and that she needs to deal and feel comfortable in her own skin. From what she said, we can infer that she wanted to inspire and engage others with her story.

Another objective of Tina's story is also about fostering collaboration. She shared postbirth story that commonly happen to many other women. By sharing her stories and participating in the campaign shows that she is no longer embarrassed with her current body appearance. Her brave action somehow could prompt other mothers to share their own stories about the topic.

The basic plot used in Tina's story is about "the quest" as Tina has moved from a point in which she feels so low about her appearance to the point where she realized that women's body do not "just bounce back" so quickly after giving birth. She also realized that she is in transition of being in motherhood and started to think that thinking about what people think about her body is not that important. Here she showed what body positivity means for her. The elements of body acceptance and love is clearly expressed in her story.

The archetype shown on this post is about "the change master". Tina shows her dedication in making a difference through a change. Her post-birth story represents transformation, self-improvement, and the desire to be the master of her own destiny. She has changed from the person who cares so much about her looks and what people said about it to a person who care less and choose to focus on a more important stuff, like transition process to motherhood. 
Table 5. \#BodyProudMums Post

\begin{tabular}{|c|c|}
\hline Photo 3 & Caption \\
\hline & $\begin{array}{l}\text { Harriet, } 26 \text { weeks after giving birth: } \\
\text { "I loved the idea of celebrating postpartum bodies. I have } \\
\text { always struggled internally with my weight and how I feel } \\
\text { about myself. I put on } 4 \frac{1}{2} \text { stone in pregnancy and have lost } \\
\text { about } 2 \frac{1}{2} \text { so far. How can I hate my body when it has given me } \\
\text { my beautiful baby boy? My body has done something amazing, } \\
\text { and to me that's the most empowering thing. } \\
\text { I feel like I'm doing this for all the mums who wear baggy tops } \\
\text { or cry when they look in the mirror. To say: you are amazing! } \\
\text { I just say to people it took me } 9 \text { months to make him - he's my } \\
\text { priority. It will come off, it just takes time. It's the people who } \\
\text { don't have children who judge the most. Other mums support } \\
\text { each other and tell them they are awesome! }\end{array}$ \\
\hline
\end{tabular}

(Source: https://www.instagram.com/p/BuYOrlyjxx_/)

Through the post Harriet showed that she did not feel at ease with her pospartum body, especially about her weight. From here, we can see that there is element of authenticity on her story. There is a sense that readers obtain from Harriet's story that makes audience believe and associate the story with reality. The way Harriet tells her story also concise enough. She went straight to her points in which she describes her appreciation towards her body as well as her spirit to cheer up her fellow mothers who may feel low about themselves.

The objective of Harriet's story are as follows: communicating who she is, sparking action, and transmitting values. Harriet is being honest about how she feels about her postpartum body. She has struggled inside, especially about her weight. However, she finally came to the understanding of giving appreciation to her body for what it has done. It was clearly stated on her sentence "How can I hate my body when it has given me my beautiful baby boy?". By joining this campaign and sharing her story, Harriet also showed her support for other mothers. She explicitly said that she wants to give credit to postpartum mothers by saying "you are amazing". By giving her support, she wants other mothers to feel amazing about themselves. In other words, her story aims to spark action. The values transmitted on this story is about body appreciation as well as body acceptance and love. They are the two most important elements of positive body image.

From the way Harriet shares her story, the researcher can infer that the basic plot used is "The Quest". She came from a point where she struggled to accept her new body to a point where she finally acknowledges that her body has done something amazing. It 
shows progression as she transformed from the place where she felt insecure about her looks to an understanding that it would take time to recover her body and that is fine with her.

The brand archetype shown on this post is the same as the rest, it is "The Change Master". It shows Harriet's understanding about her transition into motherhood. The changes happened in her body represent transformation, self-improvement, and the desire to be the master of her own destiny.

\section{DISCUSSION}

Previous researches from the psychology field by Wood-Barcalow et al. (2010), as well as the one conducted by Frisén \& Holmqvist (2010), have both resulted in a number of characteristics of body positivity. Those results have set a basic characteristic of body positivity that lay the ground for researcher to acquire what to look for on each post of \#BodyProudMums on Instagram. While those two previous researches focused on the body positivity characteristics shown by young adolescence, the characteristics shown on this research belong to postpartum women. The finding of this research shows that there were only three out of five positive body image characteristics shown on the campaign.

This research has also brought new insights on the body positivity issue on social media sphere. Previous research by Martanatasha and Primadini (2019) suggested that exposure on social media Instagram can affect the body image for young people. Meanwhile the finding of this research elaborates the kind of positive body image characteristics of women being shown on campaign on social media. This shows that as social media Instagram is proven to have effect on the way people perceive their body image, it is now being utilized to be the medium for body positivity campaign by a brand.

Comparing to the research that view body positivity from femvertising concept by Kumalaningtyas and Sadasri (2018), the setting of previous research was about the campaign by a brand which was addressed to women in general. Meanwhile, on this research, the brand campaign was specifically addressed to mothers. While the previous research described how femvertising in digital video advertisement portray body positivity issue, the result of this research showed how the elements of brand storytelling promote the message of body positivity campaign.

Other previous researches on brand storytelling by Delgado-Ballester \& FernándezSabiote (2016), Kaufman (2003), and Denning (2006) have focused on how the implementation of storytelling could enhance the communication between brand, company, and CEO towards their public. The finding of this current research is more 
focused on how the elements of brand storytelling promotes a particular issue of body positivity, and whether the issue creates good brand story for the brand behind the campaign. The story objective, the plot, and the archetype are all tailored to convey a strong message of body positivity for postpartum women and in turn create a good brand story for Mothercare.

From the findings, it was noted that not all of the five elements of positive body image are portrayed on the caption of \#BodyProudMums campaign on Instagram. The elements that are shown the most are body appreciation, body acceptance, and love. The broad conceptualization of beauty is also found although not as frequent as the previous two. However, the adaptive appearance investment and filtering information in a body positive manner part are not shown at all. Body appreciation, body acceptance, and love, as well as broad conceptualization of beauty, seems to be the core messages of the campaign itself.

That particular findings lead the reseacher to answer the first research question of how the mothers' body positivity issues being promoted by storytelling elements. The first element is good brand story. All mothers convey body positivity message through the authenticity and conciseness of their stories, and through making their stories eligible to good brand story criteria. The pospartum body image experiences that these mothers share are commonly happen to most women, thus it is easy to make the target audiences believe and associate the story with reality. The way these stories are brought also meets the conciseness criteria. They are not lengthy, instead they use simple language and get straight to the important points without eliminating the personal touch. Another element shown is reversal that emerges when there was a specific event occurred on mother's life. These events shifted their perception towards body positivity.

The second element is objectives of stories. The objective of stories found on the \#BodyProudMums campaign posts are communicating who they are; fostering collaboration; transmitting values; and sparking action. First, by communicating who they are, they have revealed their strength and vulnerability for public to see and be inspired. This creates something in common with their fellow mothers that can bring a closer engagement. Secondly, the usual and common experiences of physical and psychological changes after giving birth somehow recount a situation that the audience have also experienced, and prompts them to share their own stories about the topic. The objective of fostering collaboration was successful as there were more than two thousand other posts created using the same hashtags and featuring the same topic of postpartum experience. These first and second objectives were to capture the attention and interest of the public to look at the issue of body positivity. 
Meanwhile the third and fourth objectives intention were to transmit the values of positive body image and to spark action so that the women who see the campaign would practice this way of thinking towards themselves. While they share their stories, the values they were trying to deliver were the elements of positive body image namely body appreciation, body acceptance and love, and broad conceptualization of beauty. As public get engaged and inspired, they also want the mothers who see the campaign to do the same thing: to appreciate, accept and love their body as well as broaden their perception about beauty.

In order to deliver the message of body appreciation, body acceptance, and love, and broad conceptualization of beauty, all of the stories use the basic plot "The Quest", which means a mission and progression from point $A$ to point $B$. The mothers tell the public their shifting perception on how a postpartum body should look like, from a point where they think that postpartum women "should bounce back quickly to pre-pregnancy body" - as they have seen on media and told by people around them -- to a point where they think that their bodily changes are normal and acceptable. They have moved from a point where they pity themselves to a point where they feel empowered because they realize their body has performed miracle by giving birth to a new human being.

The last element of storytelling is "The Archetype". The use of archetypes in the brand story helps to connect with consumers in a meaningful way. Archetypes are forms or images of a collective nature that represent a typical human experience, define the personality of a brand, and give it a voice to express its story to the consumer. From the stories analyzed above, they all have the same archetype, it is "The Change Master". All mothers are shown as the characters who are strongly intuitive and dedicated to making a difference through change. They all experienced hardship in adjusting to their new postbirth body that caused them feeling insecure and lacking of confidence. However, their intuition and dedication to love their babies to the fullest have somehow direct them to a new perspective: to realize that what they experience is normal and finally find a broader conceptualization of beauty.

This brand archetype that Mothercare chooses is in accordance with the purpose of the campaign itself, which is to challenge the social standard of beautiful mothers. All bold unedited pictures have sought to normalize the motherhood experience so that all mothers could identify themselves and feel safer on their own skin. It also means to create a new term of beauty of mothers by stressing it on the tagline "Beautiful, isn't she?". "The Change Master" archetype here is clearly described and portrayed on all the photos and caption of the campaign. 
The story objectives, the basic plot, and the brand archetype of this campaign show the value that the brand wish to communicate. Mothercare would like to bring mothers to make "the quest" from the point they feel bad about their postpartum appearance to a point in which they embrace their bodily changes. The campaign would like to showcase of how women can be "the change master" who can accept their body changes (and their life) once they become a mother.

With all the elements of storytelling used to promote body positivity have been discussed above, there came the second question as to whether this issue creates a good brand story for Mothercare. There were four elements that build a good brand story: authenticity, conciseness, reversal and humor. The first two elements are shown vividly on all stories that the mothers shared. The third element was there although less frequently shown, while the fourth was not shown at all.

Humor is the element of a good story that was not used at all. It may have been because the postpartum stories are not inherently humorous by nature. By the same token, with respect to the less frequent show of reversal element, another discrepancy was identified between theory and practice. While theory has recommended the use of reversal stories as they communicate the obvious problem-solution causal relationship, the nature of postpartum stories does not always exactly consist of problem-solving part as a mark of turning point.

Some women found momentum that encourage their shift of perception towards a more positive body image, while the rest just slowly find their own way. Backed by the three elements of a good brand story (the authenticity, conciseness and reversal), \#BodyProudMums has enabled other mothers to identify themselves with the women on the campaign. Thousand posts around the world have been made following the campaign two years ago. Therefore, even though it does not have all of the four elements, this body positivity issue has made a good brand story for Mothercare.

The theoretical implications of this research is to confirm that storytelling is a suitable method to promote an issue that is close to the heart of consumers, because stories are more easily remembered (Lundqvist et al., 2013), more affective, and more convincing compared to rational arguments, statistics, or facts (Kaufman, 2003). Elements of brand storytelling can bring the issue alive, more relevant, and meaningful to public. Even if not all elements of storytelling are included, as long as the story rings true to reality, the public will be able to identify themselves with the campaign. In this case, postpartum body image is an issue closely related to Mothercare's consumer. Body positivity issue will ring a bell to postpartum mothers as they are in need of support to accompany them in 
their transition to motherhood. The messages of positive body image are naturally conveyed by mothers on the campaign. However, there should be a clearer classification on positive body image elements to clarify whether a person should meet all the four elements to have a positive body image.

The practical implication of this research is that there is still room for development of this issue of the campaign. Mothercare might want to explore another way of storytelling by emphasizing the other two elements of a good brand story: reversal and humor. On top of that, there are also two elements of positive image that have not been promoted on the stories yet, they are adaptive appearance investment and filtering information in a body positive manner. These could be presented in form of the campaign's sequel version to inspire and educate mothers all over the world.

\section{CONCLUSION}

Based on the content analysis of \#BodyProudMums campaign on Instagram, it was found that these following elements of brand storytelling: good brand story (authenticity, conciseness, reversal), story objectives (communicating who they are, fostering collaboration, transmitting values, and sparking action), basic plots (the quest and overcoming the monster), archetype (the change master) have promoted these body positivity messages, namely body appreciation, body acceptance, and love, and broad conceptualization of beauty.

There are three out of five elements of body positivity portrayed on the stories: body appreciation, body acceptance, and love, broad conceptualization of beauty. Being carried oud by the plot of "The Quest", the mothers on the stories show transformation from a point they feel so low about themselves to a point they feel empowered because of their participation on this campaign. The archetype "The Change Master" serves the message of body positivity very well as it is in line with the plot itself. The way these mothers change their perception about pospartum body have changed the way they feel about themselves.

However, given the nature of pospartum stories, not all elements of good brand story presents on the campaign, especially humor. Nevertheless, it still brings a good story for the brand, Mothercare. The most frequently used elements were authenticity and conciseness, while reversal was less frequently shown. The authenticity was the strongest element as the mothers selected for the campaign were real mothers with real stories. They are no celebrity or public figure. Thus, it really enables mothers to identify themselves with the stories on the campaign. All the story objectives, the plot, and the 
archetype, strengthen the purpose of the campaign itself: to challenge the social standard of beauty and present the rarely seen real pictures of postpartum bodies to public.

This research has several limitations, which can be seen as future research opportunities. First, the use of content analysis entails several drawbacks. First, the validity of the results may be questionable in its conclusions, methods and even approach compared to quantitative research. Second, the researcher only focused on the stories campaign from the brands' official Instagram handle. However, there are other sources of stories on \#BodyProudMums Instagram's posts that were created by unofficial mothers' personal handle, which future research should explore to provide a more holistic understanding of the characteristics of stories based on the source. Further research can also focus on the effectiveness of storytelling method on this issue by interviewing the mothers who have been the market target of this campaign.

\section{Acknowledgement}

Researcher would like to give appreciation to Lembaga Penelitian dan Pengabdian Masyarakat Universitas Al-azhar Indonesia for funding the research and supporting the researcher's participation to present this paper on the ICA Regional Conference 2019 event in Nusa Dua, Bali on Oct. 16-18, 2019.

\section{REFERENSI}

Acharya, M. (2018). The emotional branding process. In G. Ruchi, R. Chhikara, K. P. Tapan Kumar, \& A. Kataria (Eds.), Driving customer appeal through the use of emotional branding (pp. 195-208). IGI Global: Pennsylvania.

Avalos, L., Tylka, T. L., \& Wood-Barcalow, N. (2005). The Body Appreciation Scale: Development and psychometric evaluation. Body Image, 2(3), 285-297. https://doi.org/10.1016/j.bodyim.2005.06.002

Bissell, K., \& Rask, A. (2010). Real women on real beauty: Self-discrepancy, internalisation of the thin ideal, and perceptions of attractiveness and thinness in Dove's Campaign for Real Beauty. International Journal of Advertising, 29(4), 643-668. https://doi.org/10.2501/S0265048710201385

Cohen, R., Fardouly, J., Newton-John, T., \& Slater, A. (2019). \#BoPo on Instagram: An experimental investigation of the effects of viewing body positive content on young women's mood and body image. New Media \& Society, 21(7), 1546-1564. https://doi.org/10.1177/1461444819826530

Cohen, R., Irwin, L., Newton-John, T., \& Slater, A. (2019). \#bodypositivity: A content analysis of body positive accounts on Instagram. Body Image, 29, 47-57. https://doi.org/10.1016/j.bodyim.2019.02.007 
Delgado-Ballester, E., \& Fernández-Sabiote, E. (2016). "Once upon a brand": Storytelling practices by Spanish brands. Spanish Journal of Marketing - ESIC, 20(2), 115-131. https://doi.org/10.1016/j.sjme.2016.06.001

Denning, S. (2006). Effective storytelling: strategic business narrative techniques. Strategy \& Leadership, 34(1), 42-48. https://doi.org/10.1108/10878570610637885

Dewi, V. R., \& Winduwati, S. (2019). Kampanye Tubuh Positif Perempuan "Real People Real Body" oleh @Nipplets_official. Prologia, 3(2), 327-333. https://doi.org/10.24912/pr.v3i2.6352

Frisén, A., \& Holmqvist, K. (2010). What characterizes early adolescents with a positive body image? A qualitative investigation of Swedish girls and boys. Body Image, 7(3), 205-212. https://doi.org/10.1016/j.bodyim.2010.04.001

Gjerdingen, D., Fontaine, P., Crow, S., McGovern, P., Center, B., \& Miner, M. (2009). Predictors of Mothers' Postpartum Body Dissatisfaction. Women \& Health, 49(6-7), 491-504. https://doi.org/10.1080/03630240903423998

Grogan, S. (2017). Body Image: Understanding Body Dissatisfaction in Men, Women and Children. Routledge: New York

Hodgkinson, E.L., Smith, D.M. \& Wittkowski, A. 2014. Women's experiences of their pregnancy and postpartum body image: a systematic review and metasynthesis. BMC Pregnancy Childbirth 14, 330.https://doi.org/10.1186/1471-2393$14-330$

Kaufman, B. (2003). Stories that SELL, stories that TELL. Journal of Business Strategy, 24(2), 11-15. https://doi.org/10.1108/02756660310508155

Kellie, F. J. (2017). Postpartum health professional contact for improving maternal and infant health outcomes for healthy women and their infants. Cochrane Database of Systematic Reviews. https://doi.org/10.1002/14651858.CD010855.pub2

Kumalaningtyas, N., \& Sadasri, L. M. (2018). Citra Tubuh Positif Perempuan dalam Iklan Video Digital (Studi Femvertising pada Iklan Dove Real Beauty). Diakom: Jurnal Media Dan Komunikasi, 1(2), 62-73. https://doi.org/10.17933/diakom.v1i2.19

Lundqvist, A., Liljander, V., Gummerus, J., \& van Riel, A. (2013). The impact of storytelling on the consumer brand experience: The case of a firm-originated story. Journal of Brand Management, 20(4), 283-297. https://doi.org/10.1057/bm.2012.15

Maatota, F.T., Lapian, J., \& Tielung, M.V.J. (2019). Content Analysis of Storytelling Elements and Brand Archetype of LinkedIn Ad Campaign. Jurnal EMBA, 7(4), 56435653. DOI: https://doi.org/10.35794/emba.v7i4.26401

Martanatasha, M., \& Primadini, I. (2019). The relations of Self-esteem and Body Image Under the Exposure of Instagram. Ultimacomm: Jurnal IImu Komunikasi, 11(2), 158172. https://doi.org/https://doi.org/10.31937/ultimacomm.v11i2.1278

Mayring, P. (2014). Qualitative Content Analysis: Theoretical Foundation, Basic Procedures and Software Solution. Klagenfurt. Retrived from 
https://www.psychopen.eu/fileadmin/user_upload/books/ mayring/ssoar-2014mayring-Qualitative_content_analysis_theoretical_foundation.pdf

McQuail, D. (2011). Teori Komunikasi Massa. Jakarta: Salemba Humanika.

Murwani, E. (2010). Konstruksi 'Bentuk Tubuh Perempuan' Dalam Iklan Televisi. Ultimacomm: Jurnal IImu Komunikasi,2(1), 10-19. Retrieved from http://ejournals.umn.ac.id/index.php/FIKOM/article/view/401

Meireles, J. F. F., Neves, C. M., Carvalho, P. H. B. de, \& Ferreira, M. E. C. (2015). Insatisfação corporal em gestantes: uma revisão integrativa da literatura. Ciência \& Saúde Coletiva, 20(7), 2091-2103. https://doi.org/10.1590/141381232015207.05502014

Mothercare [@mothercareuk]. (2019, February 25). At Mothercare, we believe all mums are beautiful and should feel proud and confident about their bodies \#BodyProudMums Eleanor, 14 [Photograph]. Instagram. https://www.instagram.com/p/BuTWXLUlufl/

Mothercare [@mothercareuk]. (2019, February 25). At Mothercare, we believe all mums are beautiful and should feel proud and confident about their bodies \#BodyProudMums Tina, 27 [Photograph]. Instagram. https://www.instagram.com/p/BuTImwOFSYk/

Mothercare [@mothercareuk]. (2019, February 27). At Mothercare, we believe all mums are beautiful and should feel proud and confident about their bodies \#BodyProudMums Harriet, 26 [Photograph]. Instagram. https://www.instagram.com/p/BuYOrlyjxx_/

Nasucha, M. \& Kertanegara, R. (2020). The Audience's Response to Gender Relation Campaign of Ketchup Brand on Youtube, UltimaComm: Jurnal Ilmu Komunikasi, 12(1), 144-166. DOI: https://doi.org/10.31937/ultimacomm.v12i1.1323

Pandrianto, N., \& Sukendro, G. G. (2018). Analisis Strategi Pesan Content Marketing Untuk Mempertahankan Brand Engagement. Jurnal Komunikasi, 10(2), 167. https://doi.org/10.24912/jk.v10i2.2619

Patton, M.Q. (2002). Qualitative Research and Evaluation Methods. Sage Publication: London

Salzer-Mörling, M., \& Strannegård, L. (2004). Silence of the brands. European Journal of Marketing, 38(1/2), 224-238. https://doi.org/10.1108/03090560410511203

Schiffman, L. G., Kanuk, L. L., \& Wisenblit, J. (2010). Consumer behavior (10th ed). Pearson Education/Prentice Hall.

Schreier, M. (2012). Qualitative Content Analysis in Practice. Sage Publication: London

Seymour, T. (2019, February 27). New Mothercare Campaign Celebrates Reality of Childbirth. Retrieved from https://www.creativereview.co.uk/new-mothercarecampaign-celebrates-reality-of-childbirth/ 
Silveira, M. L., Ertel, K. A., Dole, N., \& Chasan-Taber, L. (2015). The role of body image in prenatal and postpartum depression: a critical review of the literature. Archives of Women's Mental Health, 18(3), 409-421. https://doi.org/10.1007/s00737-0150525-0

Taylor, J.V. (2014). The Body Image Workbook for Teens. Oakland: Instant Help Books.

Whitehead, J. (2019, February 25) New Mothercare Campaign Encourage Mothers to Feel Confident About Their Bodies. Retrieved from https://www.independent.co.uk/lifestyle/health-and-families/mothercare-body-confidence-proud-mums-campaignbirth-pregnancy-a8792406.html

Wood-Barcalow, N. L., Tylka, T. L., \& Augustus-Horvath, C. L. (2010). "But I Like My Body": Positive body image characteristics and a holistic model for young-adult women. Body Image, 7(2), 106-116. https://doi.org/10.1016/j.bodyim.2010.01.001

Woodside, A. G. (2010). Brand-consumer storytelling theory and research: Introduction to a Psychology \& Marketing special issue: Storytelling Theory and Research. Psychology \& Marketing, 27(6), 531-540. https://doi.org/10.1002/mar.20342

Worth, S. (2008). Storytelling and Narrative Knowing: An Examination of the Epistemic Benefits of Well-Told Stories. Journal of Aesthetic Education, 42(3), 42-56. 